\title{
Brazil Export Sectors. A Comparative Example with the European Market
}

Iulia-Monica DUMITRESCU ${ }^{1}$

Abstract
This paper is a short outline of the main events that have occurred in Brazil
and that have had great economic effects in the evolution of the country during history.
The aim of this paper is to bring an economic comparison between the Brazilian
economy and some European economies regarding exports.
An emphasis is made on the most relevant European countries such as
Germany, United Kingdom, Italy and France. Some of the economic sectors of Brazil
and the way the GDP is divided between them will also be highlighted. The empirical
example outlines the main categories of products that Brazil is exporting to the
European countries taken into consideration. A ranking for each of the destination
markets has been made based on the value of exports in Euros. The highest 15 values
of exports and the 10 lowest export values have been separately outlined for each of the
reference countries. The total values of exports for all categories of products for
Germany, France, Italy and United Kingdom have also been centralized in order to
obtain a more complex comparison. The results have shown interesting findings, many
traditional exports of Brazil maintain an important status alongside with modern ones.

Keywords: economic comparison, Brazil, Europe, sectors of economy, exports, product categories, exports by value

JEL classification: F1, F2, F5

DOI: $10.24818 /$ RMCI.2019.5.519

\section{Introduction}

To begin with I would like to say that this paper about the business environment in Brazil is based on my research undertaken in this country from January 2015 until December of the same year.

As a European citizen and an international business student I realized that I wanted a wider understanding about economy, and that studying on another continent would make me see the bigger picture. While choosing a country I took into consideration the advantage of the language: Spanish/Portuguese, and the origin of the people, leading me to South America. After a short study about the economic situation of Latin America, in the years of 2000-2010 there was a period of economic growth for the majority of the countries, but some of them have begun their decline in the last years, such as Argentina. The most complex country of South America, with the largest variety of economic branches and biggest as size is

\footnotetext{
${ }^{1}$ Iulia-Monica Dumitrescu, Universitatea Babes Bolyai, E-mail: iulia.dumitrescu@econ.ubbcluj.ro
} 
Brazil, so it makes a great place for any economics student that wants to begin to understand Latin America.

\section{Literature review}

The first evidence of Brazilians working together with Europeans goes back to around 1500 as in that period Brazil was also the colony with the largest amount of European settlers, since then experiencing a period of strong economic growth as presented in Furtado (1970) and demographic growth accompanied by mass immigration from Europe. In Brazil's case, statistics show that 4.5 million people immigrated to the country between 1882 and 1934(Lesser, 1999).

At the end of the 17th century, the news that large amounts of emeralds, diamonds, and gold had been found in Minas Gerais exploded in Lisbon. The region began to export 30,000 pounds of gold a year to Portugal (Bueno 2003, Azevedo and Aroldo 1971).

By 1763 the country added cotton, tobacco and sugar to gold and diamonds on its list of exports (Moreira 1981). While the interior of the country developed so did the opportunities for cattle ranching. Still, Portugal's policies at that time tended toward stripping Brazil of its resources rather than developing a truly local economy Baumann (1996).

During the rule of Dom João VI the ports were opened to trade with other nations (Barman, 1999), especially England, this defining the imperial period of Brazil as one of further development.

However Brazil's first republican government was founded on November 15, 1889 with the election of President Juscelino Kubitschek. The motto of his national development plan Longo (1990) was "Fifty years in five," therefore he opened the economy to foreign capital and offered credit to the business community. When Brasília was inaugurated in 1960 key sectors of the economy (such as the auto industry) were functioning at full steam.

During the military rule the military brought about the "economic miracle" of the 1970s (Belluzo and Gomes 2002). However, it did not last. Their major projects: from hydroelectric and nuclear power plants to the conquest of the Amazon, never completely succeeded, and inflation soared as explained by Lopes (1985). Thus leaving an inflationary problem for the years to follow and at the end of 1990 while president José Sarney finishing his term inflation was completely out of hand. Only by December 1992 when Itamar Franco took office and implemented his "Plano Real" the inflation was brought under control also as explained by Marques (1988).

In 1994, Franco was replaced by Fernando Henrique Cardoso, the former Secretary of the Treasury. Following the dictates of the International Monetary Fund, Cardoso brought about relative economic stability, but at the price of recession, cuts in health and educational programs, and a soaring national debt. His policy of selling state-owned industries, from banks to mines to phone companies, was tied to irregular practices (Pagnussat, 2015).

520 Review of International Comparative Management

Volume 20, Issue 5, December 2019 
The peaceful transition of power from Fernando Henrique to his main opposition leader, Luís Inácio Lula da Silva (elected in 2002 and re-elected in 2006), was seen as a proof that Brazil had finally succeeded in achieving a longsought political stability.

In 2008, Brazil enjoyed the economic good health to fight the global financial crisis with large stimulus packages lasting, at least, until 2014. During the Lula administration (Romero 2016), Brazilian foreign trade increased dramatically, changing from deficits to several surpluses since 2003. In 2004 the surplus reached US $\$ 29$ billion due to a substantial increase in global demand for commodities. The Lula Administration's economic policies also helped to significantly raise living standards, with the percentage of Brazilians belonging to the consumerist middle class rising from $37 \%$ to $50 \%$ of the population.

Lula was succeeded after the elections of 2010 by Dilma Rousseff, the country's first woman president. Throughout 2011, Rousseff's administration faced accusations of corruption. Meanwhile the Brazilian economy was cooling down considerably, with the gross domestic product slipping from a growth rate of about 7.5 percent in 2010 to 1.0 percent growth in 2012. In response, the central bank pursued an aggressive policy of interest-rate reduction and lowered the reserve requirement for Brazilian banks, which injected liquidity into the economy.

Brazil's political landscape was transformed by massive, sometimes violent street protests that began in São Paulo in June 2013 and spread throughout the country. The demonstrations were staged mainly by a growing middle class that was increasingly anxious about government corruption, the country's disappointing economic performance, and poor delivery of public services, especially in light of the billions spent by the government on infrastructure and to build and upgrade stadiums for the football (soccer) World Cup competition that the country would host in 2014 and Summer Olympic Games that Rio de Janiero hosted in 2016. The political scene in Brazil continues to be instable.

\section{Empirical example}

Brazil has the world's seventh largest economy by nominal GDP, and the seventh largest by purchasing power parity. The Brazilian economy is characterized by moderately free markets and an inward-oriented economy.

Brazil's economy is the largest of Latin America and the second largest in the Western Hemisphere. From 2000 to 2012, Brazil was one of the fastestgrowing major economies in the world, with an average annual GDP growth rate of over 5\%, with its economy in 2012 surpassing that of the United Kingdom, making Brazil the world's sixth largest economy. However, Brazil's economy growth has decelerated in 2013 and had almost no liquid growth throughout 2014, and the country's economy is expected to shrink by $4 \%$ in 2015.

According to the World Economic Forum, Brazil was the top country in upward evolution of competitiveness in 2009, gaining eight positions among other countries, (World Economic Forum, 2009) overcoming Russia for the first time, 
and partially closing the competitiveness gap with India and China among the BRIC economies. Important steps taken since the 1990s toward fiscal sustainability, as well as measures taken to liberalize and open the economy, have significantly boosted the country's competitiveness fundamentals, providing a better environment for private-sector development.

In the previous parts of this paper I have presented the historical background for some of the key economic events of Brazil and the initial specialization of export sectors. For a more contemporary view on the Brazilian economy with an emphasis on exports an empirical example is proposed. The European economic zone is of great importance for all Latin American countries and therefore constituting the chosen destination market for this study. The European markets preferred for this comparison are Germany, Italy, France and United Kingdom. These four countries represent the most powerful economies of the European Union and they will be the countries representing Europe in this article.

Trade data (in value) is drawn from Eurostat using the Harmonized Commodity Description and Coding System (HS nomenclature) for 2016. The largest level of sectorial disaggregation is HS6. This data was extracted from Eurostat in April 2018 (Eurostat, 2018). All harmonized system six digit codes have been extracted. The Harmonized System is an international nomenclature for the classification of products. It allows participating countries to classify traded goods on a common basis. At the international level, the Harmonized System (HS) for classifying goods is a six-digit code system. The HS comprises approximately 5,300 article/product descriptions that appear as headings and subheadings, arranged in 99 chapters, grouped in 21 sections (UN Trade statistics).

The calculations in this paper are based on totals per chapters (based on the first 2 digits of the chapter). This method was more relevant for a comparison aimed towards main categories of exports products. The values obtained as totals for each category of export have been ranked from 1 to 97 (categories "total for countries whose data are confidential" and "all harmonized system six digits codes" have not been taken into calculations). This ranking has been made based on the values of exports in Euros, as the highest value in exports was ranked 1 and the lowest value ranked 97.

Table 1. Brazilian exports to Germany (product and value)

\begin{tabular}{|c|l|c|}
\hline Ranking & Product category & Value in $€$ \\
\hline \hline 1 & Coffee, Tea, Mate And Spices & 927571253 \\
2 & Ores, Slag And Ash & 742453646 \\
3 & Residues And Waste From The Food Industries & 454496638 \\
4 & Electrical Machinery And Equipment And Parts Thereof & 453656922 \\
\hline 5 & Paper And Paperboard; Articles Of Paper Pulp & 413227101 \\
6 & Ships, Boats And Floating Structures & 318039715 \\
7 & Oil Seeds And Oleaginous Fruits; Miscellaneous Grains & 223527834
\end{tabular}

522 Review of International Comparative Management $\quad$ Volume 20, Issue 5, December 2019 


\begin{tabular}{|c|l|c|}
\hline Ranking & Product category & Value in $€$ \\
\hline \hline 8 & Tobacco And Manufactured Tobacco Substitutes & 167362350 \\
9 & Inorganic Chemicals & 110774641 \\
10 & Preparations Of Meat, Of Fish Or Of Crustaceans, Molluscs & 109977343 \\
11 & Meat And Edible Meat & 102513061 \\
12 & Railway Or Tramway Locomotives, Rolling-Stock And Parts & 88515660 \\
13 & Iron And Steel & 82530254 \\
14 & Aircraft, Spacecraft, And Parts Thereof & 78745402 \\
15 & Articles Of Leather; Saddlery And Harness; Travel Goods & 76230527 \\
$\ldots$ & & \\
88 & Articles Of Stone, Plaster, Cement, Asbestos & 20374 \\
89 & Manufactures Of Straw & 19389 \\
90 & Tanning Or Dyeing Extracts; Tannins And Their Derivatives & 19200 \\
91 & Wadding, Felt And Nonwovens; Special Yarns; Twine & 16811 \\
92 & Umbrellas, Sun Umbrellas, Walking-Sticks, Seat-Sticks & 10772 \\
93 & Live Animals & 7200 \\
94 & Special Woven Fabrics; Tufted Textile Fabrics; Lace & 5314 \\
95 & Pulp Of Wood Or Of Other Fibrous Cellulosic Material & 0 \\
96 & Prepared Feathers And Down And Articles Made Of Feathers & 0 \\
97 & Zinc And Articles Thereof & 0 \\
\hline & Source: Eus & \\
\hline
\end{tabular}

Source: Eurostat, Calculations by author based on data extracted in 2018

For the exports of Brazil to Germany in 2016 the main export categories are: coffee, tea, mate and spices; ores, slag and ash; residues and waste from the food industries. Many of the other top 10 products are evolving around machinery (electrical machinery/equipment parts, ships, boats and floating structures) that is based on metallurgic industry. Another important industry that has high values in exports in more categories is the food industry (meat and edible meat, residues and waste from the food industries).

Table 2. Brazilian exports to France (product and value)

\begin{tabular}{|c|l|c|}
\hline Ranking & Product category & Value in $€$ \\
\hline \hline 1 & Residues And Waste From The Food Industries & 600912575 \\
2 & Ores, Slag And Ash & 348736676 \\
3 & Paper And Paperboard; Articles Of Paper Pulp & 218408245 \\
4 & Coffee, Tea, Mate And Spices & 130681580 \\
\hline 5 & Electrical Machinery And Equipment And Parts Thereof & 104909225 \\
6 & Oil Seeds And Oleaginous Fruits; Miscellaneous Grains & 104212316 \\
7 & Cork And Articles Of Cork & 76919505
\end{tabular}




\begin{tabular}{|c|l|c|}
\hline Ranking & Product category & Value in $€$ \\
\hline \hline 8 & Articles Of Iron Or Steel & 62347953 \\
9 & Headgear And Parts Thereof & 56841633 \\
10 & Fertilisers & 55846502 \\
11 & Mineral Fuels, Mineral Oils And Products Of Their Distillation & 55311269 \\
12 & Railway Or Tramway Locomotives, Rolling-Stock And Parts & 50332375 \\
13 & Aircraft, Spacecraft, And Parts Thereof & 30975811 \\
14 & Tobacco And Manufactured Tobacco Substitutes & 21967659 \\
$\ldots$ & & \\
88 & Tanning Or Dyeing Extracts; Tannins And Their Derivatives & 11212 \\
89 & Articles Of Stone, Plaster, Cement, Asbestos & 10758 \\
90 & Cereals & 6147 \\
91 & Live Animals & 4048 \\
92 & Miscellaneous Chemical Products & 3291 \\
93 & Vegetable Plaiting Materials; & 1645 \\
94 & Manufactures Of Straw & 1210 \\
95 & Prepared Feathers And Down And Articles Made Of Feathers & 772 \\
96 & Live Trees And Other Plants; Bulbs, Roots And The Like & 386 \\
97 & Other Base Metals; Cermets; Articles Thereof & 0 \\
& & \\
\hline & Source: Eurostat, Calculations by author based on data extracted \\
\hline
\end{tabular}

Source: Eurostat, Calculations by author based on data extracted in 2018

In the case of Brazilian exports to the French market, food industry related categories (residues and waste from the food industries; coffee, tea, mate and spices; oil seeds and oleaginous fruits; miscellaneous grains) take a more central position in ranking. However metallurgic industry related categories are present in higher number in the first 15 positions from Table 2.

Table 3. Brazilian exports to Italy (product and value)

\begin{tabular}{|c|l|c|}
\hline Ranking & Product category & Value in $€$ \\
\hline \hline 1 & Paper And Paperboard; Articles Of Paper Pulp & 522967394 \\
2 & Coffee, Tea, Mate And Spices & 463120410 \\
3 & Ores, Slag And Ash & 351917643 \\
4 & Articles Of Leather; Saddlery And Harness; Travel Goods & 288749351 \\
5 & Articles Of Iron Or Steel & 205824960 \\
\hline 6 & Oil Seeds And Oleaginous Fruits; Miscellaneous Grains & 179922593 \\
7 & Meat And Edible Meat & 163307225 \\
8 & Electrical Machinery And Equipment And Parts Thereof & 161370438
\end{tabular}

524 Review of International Comparative Management

Volume 20, Issue 5, December 2019 


\begin{tabular}{|c|l|c|}
\hline Ranking & Product category & Value in $€$ \\
\hline \hline 9 & Iron And Steel & 121113594 \\
10 & Salt; Sulphur; Earths And Stone; Plastering Materials & 90616562 \\
11 & Mineral Fuels, Mineral Oils And Products Of Their Distillation & 71576325 \\
12 & Rubber And Articles Thereof & 65647961 \\
13 & Lead And Articles Thereof & 62032046 \\
14 & Residues And Waste From The Food Industries & 50453414 \\
15 & Printed Books, Newspapers, Pictures & 44020873 \\
$\ldots$ & Articles Of Stone, Plaster, Cement, Asbestos & 9424 \\
88 & Preparations Of Cereals, Flour, Starch Or Milk & 9286 \\
90 & Man-Made Filaments & 8311 \\
91 & Special Woven Fabrics; Tufted Textile Fabrics; Lace & 7773 \\
92 & Musical Instruments; Parts And Accessories Of Such Articles & 7622 \\
93 & Live Animals & 0 \\
94 & Pulp Of Wood Or Of Other Fibrous Cellulosic Material & 0 \\
95 & Prepared Feathers And Down And Articles Made Of Feathers & 0 \\
96 & Zinc And Articles Thereof & 0 \\
97 & Other Base Metals; Cermets; Articles Thereof & 0 \\
\hline
\end{tabular}

Source: Eurostat, Calculations by author based on data extracted in 2018

Alongside the metallurgic industry related categories and the food industry related categories in table 3 reflecting the Brazilian exports to Italy another important industry appears. The cellulose industry is related to the category with the highest values in exports, the paper and paperboard; articles of paper pulp category. Another category related to the same industry is printed books, newspapers, pictures ranking as 15 by value of exports.

Table 4. Brazilian exports to United Kingdom (product and value)

\begin{tabular}{|c|l|c|}
\hline Ranking & Product category & Value in $€$ \\
\hline \hline 1 & Iron And Steel & 737432864 \\
2 & Preparations Of Meat, Of Fish Or Of Crustaceans, Molluscs & 230020251 \\
3 & Electrical Machinery And Equipment And Parts Thereof & 172947206 \\
4 & Ships, Boats And Floating Structures & 159067996 \\
5 & Ores, Slag And Ash & 154299453 \\
6 & Edible Fruit And Nuts; Peel Of Citrus Fruits Or Melons & 154252143 \\
\hline 7 & Oil Seeds And Oleaginous Fruits; Miscellaneous Grains & 141158011 \\
8 & Meat And Edible Meat & 127301085 \\
9 & Paper And Paperboard; Articles Of Paper Pulp & 114900052
\end{tabular}




\begin{tabular}{|c|l|c|}
\hline Ranking & Product category & Value in $€$ \\
\hline \hline 10 & Coffee, Tea, Mate And Spices & 99013352 \\
11 & Residues And Waste From The Food Industries & 93321828 \\
12 & Cork And Articles Of Cork & 91578345 \\
13 & Toys, Games And Sports Requisites; Parts And Accessories & 78524187 \\
14 & Printed Books, Newspapers, Pictures & 75456381 \\
15 & Inorganic Chemicals & 66836224 \\
$\ldots$ & & \\
84 & Umbrellas, Sun Umbrellas, Walking-Sticks, Seat-Sticks & 9977 \\
85 & Other Vegetable Textile Fibres; Paper Yarn And Woven Fabrics & 7195 \\
86 & Live Trees And Other Plants; Bulbs, Roots And The Like & 6684 \\
87 & Musical Instruments; Parts And Accessories Of Such Articles & 5533 \\
88 & Live Animals & 0 \\
89 & Vegetable Plaiting Materials; & 0 \\
90 & Miscellaneous Chemical Products & 0 \\
91 & Manufactures Of Straw & 0 \\
92 & Pulp Of Wood Or Of Other Fibrous Cellulosic Material & 0 \\
93 & Wadding, Felt And Nonwovens; Special Yarns; Twine & 0 \\
94 & Special Woven Fabrics; Tufted Textile Fabrics; Lace & 0 \\
95 & Prepared Feathers And Down And Articles Made Of Feathers & 2018 \\
96 & Zinc And Articles Thereof & Tin And Articles Thereof \\
97
\end{tabular}

Source: Eurostat, Calculations by author based on data extracted in 2018

For the British market an interesting fact appears, between the four destination markets it is the one with the highest number of categories with a value of $0 €$ in exports. Those categories are: live animals; vegetable plaiting materials; miscellaneous chemical products; manufactures of straw; pulp of wood or of other fibrous cellulosic material; wadding, felt and nonwovens; special yarns; twine; special woven fabrics; tufted textile fabrics; lace; prepared feathers and down and articles made of feathers; zinc and articles thereof; tin and articles thereof.

Another interesting view would be the comparison in values in Euro of exports from Brazil for all product categories to the considered countries. 
Table 5. Total exports to Germany, France, Italy, UK

\begin{tabular}{|l|r|}
\hline Destination markets & Total exports from Brazil; for all categories of products \\
\hline Germany & $\mathbf{5 1 6 1 0 6 1 7 9 5}$ \\
\hline France & 2207570155 \\
\hline Italy & 3223214960 \\
\hline United Kingdom & 2938839167 \\
\hline
\end{tabular}

While comparing the total values of exports for Germany, France, Italy and United Kingdom we can first observe that all values are in the area of billions of Euros. Clearly not all countries have the same value of exports from Brazil. The most valuable destination country was Germany out of the economies presented in this example. German imports from Brazil in 2016 are summed up to 5161061795€. This makes the difference between Germany (with the highest value) and Italy (with the second highest value) to be a considerable one, valuing more than 1 billion Euros. The difference in value is the highest between the first and the second country whereas between the countries that Brazil exports to less is smaller.

\section{Conclusions}

In the first part of this paper a selection of the most important economic events that occurred in modern Brazil was presented. The aim of the presented events was to bring a historical background surrounding the first economic activities of the country in relationship with Europe, regarding specialization in products and initial exports. For a comparison with the current situation of the Brazilian exports/specialization an empirical example was suggested.

The destination countries chosen are the most important economies from Europe and constitute old trade partners of Brazil. These countries baring a representative stand in this study, and they are: Germany, France, Italy and UK. The data extracted reflects the trade between Brazil and the four European countries in 2016. For each of these countries a ranking has been made based on value of exports in $€$ depicting the most exported categories of products. Each of these countries presents a table with the 15 highest values and 10 lowest values in export. These tables were made in a similar manner in order to facilitate the comparison process.

To begin with, all four European economies have categories of products that are present in the ranking of highest values, such as: residues and waste from the food industries, prepared animal fodder. From this category the highest values for all four countries came from the subcategories: 230400(Oil-cake and other solid residues, whether or not ground or in the form of pellets, resulting from the extraction of soya bean oil) and 230990 (Complete feeds, for poultry, for swine, for cattle, bird seeds). Germany and France also import the subcategories 230320 (Beet-pulp, bagasse and other waste of sugar manufacture) and 230910 (Dog or cat 
food, put up for retail sale, in airtight containers) and on the other hand only Italy imports the subcategory 230500 (Oil-cake and other solid residues, whether or not ground or in the form of pellets, resulting from the extraction of ground-nut oil). Although residues and waste from food industries are a more modern specialization of Brazilian economy hey account for high values in export to Europe.

One of the oldest products exported from Brazil to Europe was coffee, today it also represents some of the highest values in export, as the category of trade coffee, tea, mate and spices is in the top 10 ranking for all countries. More so in Germany it is the primary export product, in Italy second and in France the $4^{\text {th }}$ most exported product.

All four countries export different categories related to the metallurgic industry (iron and steel), mining industry (ores, slag and ash), food industry (edible fruit and nuts; peel of citrus fruits or melons; oil seeds and oleaginous fruits; miscellaneous grains; meat and edible meat, preparations of meat, of fish or of crustaceans, mollusks), cellulose industry (paper and paperboard; articles of paper pulp; printed books, newspapers, pictures) and machinery (electrical machinery and equipment and parts thereof; ships, boats and floating structures).

In conclusion Brazil is exporting diverse categories of products towards the European market, in high values. Some of the most classic products such as coffee are still among the most important export categories whereas some new categories appear to have the attention of the European market. The country that has continental sizes and is lucky enough to essentially have all the main types of resources, manages to productively extract and process them. Said productivity is expressed in numerous industries that Brazil specializes in and is reflected in the great values of exports to Europe. Based on the presented data the European countries rely of Brazil for a large number of imported goods.

\section{References}

1. Luiz Gonzaga Belluzo, Julio Gomes de Almeida (2002), Depois da queda, Editura Civilizacao Brasileira, Rio de Janeiro

2. Aroldo de Azevedo (1971), O Brasil e suas regiões, Editura Companhia Editora Nacional, São Paulo.

3. Bueno Eduardo (2003), Brasil: uma História, Editura Atica. São Paulo.

4. Jeffrey Lesser (1999)., Negotiating national identity-Immigrants, Minorities, and the Struggle of Ethnicity in Brazil, Duke University Press, pp. 3-23.

5. Francisco Lafaiete Lopes (1985), Inflacao inercial, hiperinflacao $e$ desinflacao, notas e conjecturas, Revista de economia politica, volume 5(2).

6. Maria Silvia Bastos Marques (1988)., O plano Cruzado: teoria e practica, Revista de economia politica, vol 8, no.3.

7. Pagnussat, J. L. (2015), Em defesa do interesse nacional: desinformação e alienação do patrimônio público. Revista Do Serviço Público, 46(1), pp. 199 201.

528 Review of International Comparative Management

Volume 20, Issue 5, December 2019 
8. Renato Baumann (1996), O Brasil e a economia global, Editura Elsevier, Rio de Janeiro.

9. Celso Furtado (1970), Formacao economica da America Latina, Editura LIA, Rio de Janeiro.

10. Carlos Alberto Longo (1990), Plano Collor, Editura Ano Internacional de Alfabetizacao.

11. Barman Roderick J. (1999), Citizen Emperor: Pedro II and the Making of Brazil, 1825-1891, Stanford University Press.

12. Simon Romero (2016), Ex-President 'Lula' Joins Brazil's Cabinet, Gaining Legal Shield, New York Times 2016, May.

13. Eurostat database [online],

Available at: < https://ec.europa.eu/eurostat/data/database>, Accessed January 2018.

14. United nations international trade statistics [online], Available at: $<$ https://unstats.un.org/unsd/tradekb/Knowledgebase/50018/HarmonizedCommodity-Description-and-Coding-Systems-HS> Accessed November 2019.

15. World Economic Forum (2009), The Global Competitiveness Report 20092010, World Economic Forum, Switzerland.

Available online at: <http://www3.weforum.org/docs/WEF_Global CompetitivenessReport_2009-10.pdf>, Accessed November 2019. 